Article

\title{
Constructing the Green Supply Chain for Rural Tourism in China: Perspective of Front-Back Stage Decoupling
}

\author{
Jue Chen ${ }^{1}$, Jingjing Guan ${ }^{1, *}$, Jing (Bill) $\mathrm{Xu}^{2}$ and Cecile Clergeau ${ }^{3}$ \\ 1 School of Tourism Management \& Urban-rural Planning, Zhejiang Gongshang University, \\ Hangzhou 310018, China; chenjue@zjgsu.edu.cn \\ 2 School of Professional Education and Executive Development, The Hong Kong Polytechnic University, \\ Hong Kong, China; spbill@speed-polyu.edu.hk \\ 3 School of Economics and Management, University of Nantes, Nantes 44322, France; \\ cecile.clergeau@univ-nantes.fr \\ * Correspondence: jjguan66@zjgsu.edu.cn; Tel.: +86-571-2800-8168
}

Received: 2 October 2018; Accepted: 13 November 2018; Published: 19 November 2018

\begin{abstract}
Rural tourism serves as an important engine for rural development, but also brings environmental pressure. The balance between sustainability and local economic benefits is critical to rural tourism development in developing countries. Incorporating the theories of green supply chain and front-back stage decoupling, this paper proposes a new model of green tourism supply chain for rural tourism to relieve the dilemma between economic efficiency and environmental sustainability. Back-stage functions have been decoupled from individual rural tourism service units to form shared service centers, which centralize the provision of back-stage functions and generate an independent tier of suppliers in the green Tourism Supply Chain (TSC). Field practice experiences relating to green TSC construction and operation are also discussed. The new structure of green supply chain shows positive environmental and economic effects of rural tourism. It increases the tourism business efficiency without sacrificing the local environment. The paper intends to present a new perspective and explores a new research path to green supply chain research in tourism and other service industries which have been previously limited in manufacturing framework and provide some insights into tourism destination practice.
\end{abstract}

Keywords: green supply chain; rural tourism; front-backstage decoupling; case study

\section{Introduction}

Rural tourism acts as an important engine for rural development and revitalization [1-3]. It can reduce unemployment, boost the regional economy, improve the living standard of local populations, and decrease the imbalance between urban and rural life [4-6]. However, growing rural tourism also has negative consequences for the countryside, especially environmental pressure. Increased tourist activities in the rural area cause the air, water, and earth to increasingly face the risk of contamination owing to the construction of tourism infrastructures and facilities, as well as damage from the tourism business operations that cater to tourists' needs [7].

Preservation of the environment is especially critical to rural areas. Bramwell [8] (p. 2) stated that "a crucial point in many developed countries is the especially high regard in which the countryside is held: it is seen as special and therefore particularly worthy of protection." According to Bramwell, "special" refers to the physical fragility of rural area, and also to the unique rural environment that fulfills people's views about the high quality of life in the countryside. These are the key elements 
attracting tourists to the countryside [9]. The importance of environmental protection in rural areas has led to the argument that rural tourism is synonymous with sustainable tourism development [4].

In reality the conflict between economic development and environmental protection has become one of the challenges that stakeholders in rural tourism have to face up to.

Rural tourism in China has developed rapidly in the last three decades. In 2016, rural areas saw 2.1 billion tourists and generated over US\$90 billion in local income for [10]. However, the rural environment also faces challenges from rural tourism development. Case studies of the Fuxian Lake area [11], Guanhou village [12], and Meijiawu village [13] indicated that the lake and underground stream were contaminated by the sewage produced by restaurants and lodgings in the areas. The increased amount of solid waste exceeded the garbage processing capacities of the communities, and the unapproved construction project ruined the rural landscape. The environmental crisis may not be unique to China, but China offers a specific context. In contrast to communities in developed countries, which are positively inclined toward adopting sustainable tourism practices [14,15], residents in China's rural areas generally place more weight on economic income than environmental benefits $[4,13]$. Recently, reports from Dali, Yunnan province showed that because of the direct discharge of sewage from surrounding restaurants and hotels, Erhai Lake-which is the main tourism attraction of Dali-had an explosive growth of blue algae in 1996, 2003, and 2013. To save the water quality of Erhai Lake, on 31 March 2017 the Dali government announced a year-long closure of more than 1000 hotels and restaurants, a step that would significantly influence local communities' income [16].

The question of how to relieve the conflict between environmental sustainability and local economic benefits becomes a critical issue in China's rural tourism development. While in the related research area, green supply chain (GSC) is regarded as the key to satisfy both efficiency and environment consideration. However, studies of GSC in tourism remain scarce and are constrained within the framework of manufacturing which the GSC originated from. Considering that the front-back stage structure is the fundamental feature of service delivery system, this paper proposes a model of green supply chain for rural tourism from a new perspective: the front-backstage decoupling which is regarded as an advanced service system structure. The implementation of the model can reduce the negative impacts of rural tourism on the environment, and at the same time increase the efficiency of the tourism supply system. All these benefits are critical to the sustainable development of rural tourism, especially in the areas attracting large amount of rural tourists. To test the model, this paper uses Baofu town in Zhejiang Province as a case study. The paper tries to bring a new research perspective and new research path for GSC in tourism and sustainability in rural tourism.

\section{Literature Review}

\subsection{Supply Chain in Tourism Industry: From Distribution Channel to Destination-Based Service Network}

TSC is in nature a kind of Service Supply Chain (SSC) which refers to activities that allow the service to function effectively on while [17]. SSC research has gained significance due to the increasing importance of the service sector in economy. However, the main body of the SCM studies still focuses on the manufacturing sector [18]. The literature on SSC remains relatively nascent [19]. These studies are underpinned by specific theoretical perspectives, among which a central theme is the customer's involvement and role in service delivery [20]. Based on this understanding, SSC studies emphasized on interactions between customers and service providers, information sharing, knowledge exchange and collaboration to improve service delivery [21,22]. Therefore, the focus of SSC is different from TSC. TSC has its own industrial context. The understanding of the TSC structure has developed over time. In the beginning, the TSC was merely recognized on the organizational level as a channel of distribution for tourism products [23]. Later, it became a tool for analysis of the entire industry. Suppliers offering tourism products and services constitute parts of the supply chain [24] and are further classified as direct and indirect suppliers. Typical direct suppliers, known as tier 1 suppliers, 
include accommodation, transportation, excursion and tour operators, and travel agents, and tier 2 suppliers are those supplying services or products to tier 1 supplier [25]. The service flow is from the tier 2 suppliers to tier 1 supplier and then to the customer, while the direction of information flow is opposite. In an attempt to include any suppliers related to tourists' services in the TSC, the concept of tourism destination supply chain (TDSC) was proposed [23]. In the TDSC model, government, public service organizations, non-profit organizations, and local communities are grouped as tourism public service suppliers, while tourism service and manufacturing suppliers are grouped as tourism commercial suppliers [23]. As these suppliers connect and interweave, the TDSC has a network rather than chain structure. TDSC concept reveals the complex relationship between tourism businesses and organizations in tourism destination, and the importance to develop the destination from a holistic view.

\subsection{Green Supply Chain: Balance Thinking for Both Efficiency and Environment}

The objectives of traditional supply chain management are to reduce costs and improve efficiency, with little concern for the environmental dimension [26]. In the last decade, external circumstances have forced enterprises to consider the environmental dimension when supply chain networks are designed [27]. Developed in 1996 by the Manufacturing Research Consortium of Michigan State University, GSC has emerged as a way to combine environmental protection and supply chain management [28]. GSC is regarded "as an important new archetype for enterprises to achieve profit and market share objectives by lowering their environmental risks and impacts while raising their ecological efficiency" ([29] p. 450) [30].

Understanding and design of GSC structure (network) has been discussed in manufacturing context. GSC network consists of four tiers: retail, wholesale, manufacturing end products, and manufacturing raw materials [31]. Other work suggests that the GSC could be a closed loop circle. The inclusion of reverse logistics transforms the chain structure of GSC into a ring, with multiple enterprises involved in the circle [29]. Namely, it includes the suppliers to the manufacturer then to customers, and finally closes the loop (reverse logistics) via the logistics service provider with the help of the customer [32]. Suppliers and customers become the part of the companies 'upstream integration and downstream integration respectively; between upstream and downstream is the logistics service which takes an important role in minimizing the environmental impact through the reverse logistics; the company becomes the hub in the cooperation of customers, suppliers, and logistics service providers. It not only takes care of the environmental issues, also minimize the negative environmental impact by the cooperation [33].

The studies mentioned above offer useful frameworks (structure) of GSC for industry practice. However, most frameworks of GSC are designed for the manufacturing sector rather than the service sector. Because of the differences between the service and manufacturing industries, the tourism/hospitality industry must create its own GSC with its unique features. Several studies have made great effort to create GSC for the tourism industry (e.g., [23,25,34-36]).

\subsection{Green Supply Chain in Tourism Studies: Lack of Consideration on Service Features}

Although reference to green supply chains is scarce in the tourism literature, some authors have alluded to or touched on the concept. Tapper and Font [24], Fadeeva [37], and Edgell [38] offered a preliminary discussion of the incorporation of sustainable development into the TSC. Taking tour operators and tourist attraction as the hub of the TSC, Sigala [35] and Wu [39] created frameworks of green TSC. Wang [40] proposed the operation mechanism of green tourism supply chain with scenic spots as core-enterprises. Zhang [41] applied the important principles of green supply chain management on ecotourism product development. Zhou and Wang [42] proposed a green supply chain model which can be used to transfer urban resource to the rural tourism development. More recently, $\mathrm{Xu}$ and Gursoy [37] proposed a sustainable TSC, in which the tier 1 and tier 2 suppliers are renamed as upstream suppliers, midstream suppliers, and retailers. The structure of a sustainable TSC 
is similar to that of a traditional supply chain, but the actions, motivators and inhibitors, company characteristics, evaluation approaches, and impacts for the sustainable TSC differ.

The above studies provide insightful knowledge of sustainable/green TSC and showed the importance of green TSC in tourism development. Applying GSC into tourism industry can minimize the negative influence caused by tourists' growth. However, the exploration of green TSC is still insufficient, and also the frameworks proposed by these studies mostly follow a traditional theory of supply chain for manufacturing industry, in which sustainable development is incorporated into product design, purchasing, production, marketing, and consumption. Given the nature of the service industry, the design of green TSC has to sufficiently consider the mechanism of service product supply and the characteristics of the tourism industry.

\subsection{Front-Back Stage Decoupling: Solution to Both Efficiency and Environment in Service Operations}

Front and back stage systems are regarded as the basic structure of the service delivery process [43]. The criterion used to differentiate the front and back stages is customer contact, which is regarded as one of the most distinguished features of service provision [44]. The front stage is the service system part. In the front stage, service activities require customer contact. Hence these service activities are directly experienced by customers. In contrast, the back stage refers to the processes that are carried out without customer contact and cannot be noted by customers. Therefore, the design of the front office highlight the quality of service that can be experienced via customer contacts, while the back-office design always adopts the manufacturing principles emphasizing on efficiency [45,46].

As an upgraded version of the front-back stage structure, the decoupling of front-back stage has aroused both academic and industrial concern since 1990s when banking industry-initiated process re-engineering based on this concept. The decoupling of the front and back stages underlines the mobility, centralization, and industrialization of backstage functions [47]. Owing to technology development, back-stage functions have become more "movable" and can be geographically decoupled from the service system. The relocated backstage functions usually comprise shared service centers (SSCs) [48] and are placed in countries with lower costs in terms of labor, land rent, materials, and $\operatorname{tax}[49,50]$. The shared service center, as a practice of the back-stage functions of centralization, commercialization, and industrialization, generates a higher degree of efficiency due to economy of scale [51-53]. The implementation of a shared service center also has environmental benefits, since the back-stage functions can be moved away from the environmentally sensitive areas and a large-scale operation of back-stage functions can adopt more anti-pollution methods [54].

The decoupling of the front and back stages has both economic and environmental significance. In many service sectors, such as banking business, telecommunications, and IT service, the frontand back-stage decoupling and shared service center have been widely applied and have generated positive outcomes [47]. However, in the tourism field these specific topics call for more academic research and practice [54].

\section{Constructing a Green Rural Tourism Supply Chain Model Based on Front-Back Stage Decoupling Concept}

On the basis of the preceding literature review and analysis, this paper proposes a synthetic framework for a green supply chain in the context of Chinese rural tourism (Figure 1). The framework comprises both intangible and tangible product suppliers of rural tourism. Intangible produce suppliers are mainly marketing corporations, reigning institutions, local governments, and non-profit organizations [23]. Tangible product suppliers are those types of corporations consistent with frameworks in recent studies (e.g., [25,37])

The upstream end of green TSC for rural tourism has three tiers. Tier 1 involves suppliers that directly contact tourists and offer tourism service and products. Farmhouses, working farms, and local restaurants are typical suppliers in tier 1 for rural tourism. Tier 2 comprises some back-stage functions that are outsourced from tier 1 corporations, such as the primary processing of food, the 
manufacture of handicrafts, laundry, marketing, training, and recycling. Shared service centers might be established to operate these back-stage functions. Some shared service centers purchase, produce, and deliver their tangible products to or receive wastes from the first-tier suppliers via logistics providers, while other shared service centers offer services like marketing or human resource training to first-tier suppliers. Tier 3 members mainly include businesses such as local farms, food and beverage manufacturers, equipment and furniture manufacturers, craft producers, water and energy suppliers, and waste recycling and disposal, as well as institutional suppliers such as local government, non-profit organizations, and educational institutions. Tier 3 entities serve first-tier suppliers directly or indirectly via suppliers in the second tier.

Vertically, the green TSC for rural tourism is segmented into three layers based on the types of products offered at the beginning of the sub-chain and the logistic flow. In the surface layer, logistics flow through the initial suppliers to the end users to deliver tangible products. The middle layer's service flow mainly offers intangible products through the supply chain without the involvement of logistic corporations. The deepest layer has a reversed logistic flow, which is from the downstream to the upstream of the supply chain. The downstream end includes tourists participating in rural tourism.

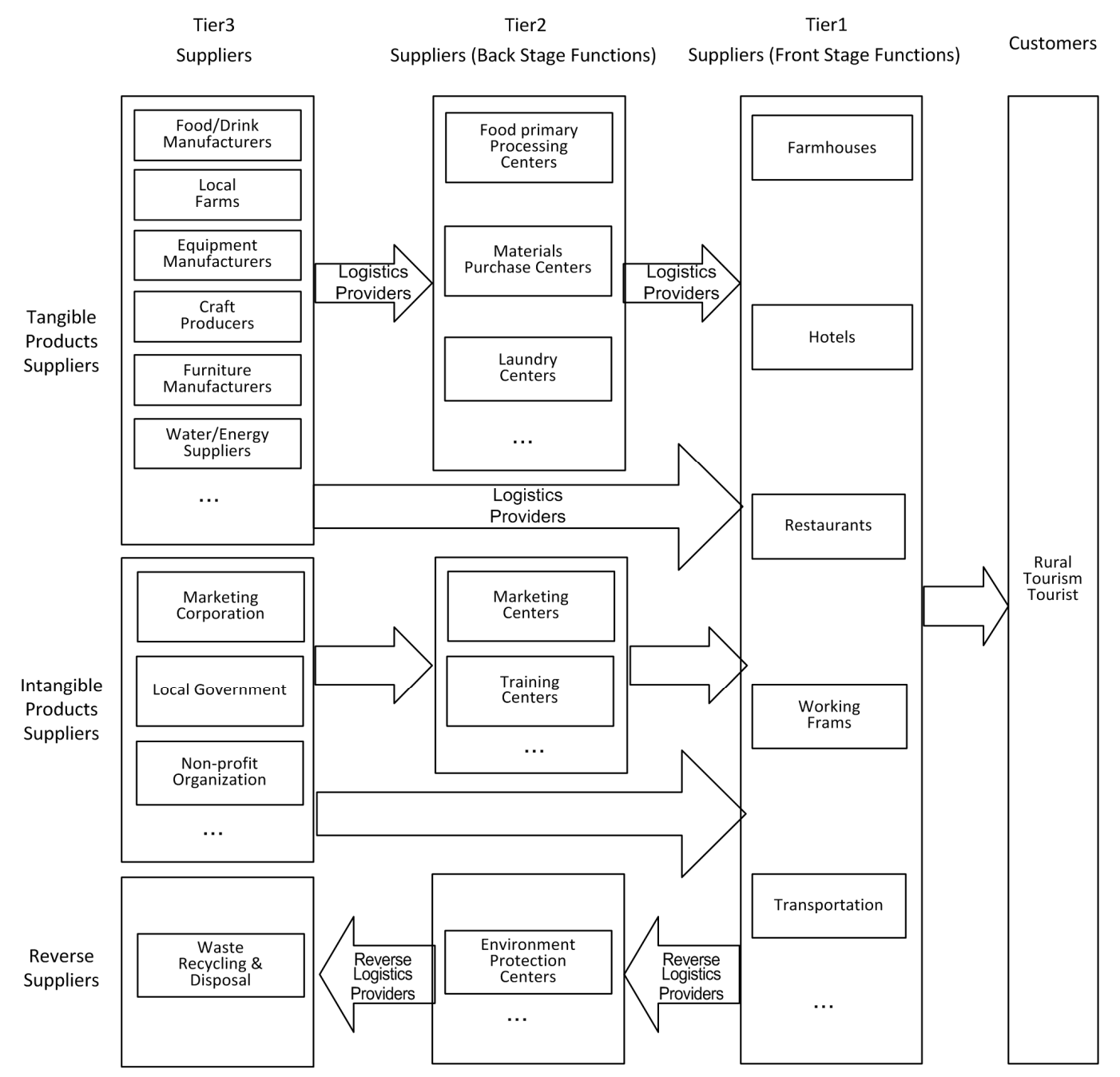

Figure 1. Green tourism supply chain (TSC) for rural tourism.

The framework of green TSC for rural tourism has innovative structures differentiating it from structures developed by previous studies. First, an extra tier is added to the framework based on the theory of front- and back-stage decoupling. The additional upstream tier consists of different shared service centers offering various back-stage functions to the first-tier suppliers. The shared service 
centers are based on system decoupling, in which supporting corporate functions such as finance, HR, purchasing, IT, and legal services are separated from original corporations and integrated into a new central unit, reporting outside of the divisional line hierarchy [55]. The new added tier (i.e., shared service centers) significantly affects the balance between environmental protection and growth in the local economy. Environmentally, contaminants produced by tourism suppliers can be centralized and processed at shared service centers by applying specialized high-tech processing systems. The large-scale operation of pollution treatment is much more efficient than small-scale scattered operations of individual corporations. On the other hand, the shared service centers can be located in some suitable place, alleviating the increasing pressure on the environment of local rural areas. Economically, the shared and centralized or even industrialized back-stage function operations improve resource utilization and reduce operational costs, increasing corporations' profits. The centralized quality control conducted by the shared service center can minimize the instability of service quality offered by individual small-scale corporations in the rural areas and bring tourists a better environment and better service as well as a lower product price because of reduced operational costs.

Second, as noted above, this framework distinguishes intangible product suppliers from tangible product suppliers. Typical organizations of the first category include marketing corporations, IT design corporations, educational institutions, and local government. The inclusion of suppliers offering intangible products responds to scholars' suggestions that environmental protection requires not only dealing with technical constraints but also responds to social forces, such as administration, education, information, and finance [56]. The involvement of social forces can facilitate the effectiveness of environmental protection to create a favorable environment for rural tourists.

In this paper, the green TSC model for rural tourism is used to analyze how the constructed supply chain can improve environmental protection for rural tourism and simultaneously increase local corporations' economic benefits. The framework is applied in a case study of the town of Baofu in Zhejiang Province, China. Lessons from the case study are summarized and discussed to generate future strategies for green TSC in rural tourism.

\section{Methods}

\subsection{Research Context}

The town of Baofu is one of the fifteen towns located in and governed by Anji Country, Zhejiang Province. It has 18,000 residents scattered among 10 villages and 1 residential district and is known for its rural tourism development during the last decade. As a part of the Yangtze River Delta, which is one of the most economically advanced regions in China, Baofu town has a large potential market for rural tourism. Small-scale and family-operated businesses are the basic units of its rural tourism. Baofu town was one of the most advanced towns in Anji Country in terms of economic development, and also among the top list of rural tourism. In 2008, five owners used their own proprieties to operate family-run hotels (nong jia le) and serve rural tourists from surrounding cities. Tourist can stay in the farmhouses 1 to 2 nights and enjoy local food and other leisure activities in rural areas. Owing to the peaceful and clean environment, beautiful landscape, and fresh and organic food, Baofu town attracted growing numbers of tourists, which brought huge profits to proprietors. The numbers of family-run hotels increased from 68 (2011) to 76 (2012) to 110 (2016). According to the most recent statistical data, more than 3000 beds and 6000 dining seats are available for visitors. The rapid development of rural tourism brought much economic benefit to the local business dealers. The local government also benefited from the increasing tax revenue and employment as well as recognition from both the superior government and local communities. In 2015, Baofu town has been awarded as one of the five "Model Towns for Rural Tourism" by Anji Country government.

However, the trend of rural tourism development in Baofu town also had setbacks, and the second half of 2012 was a turning point. From 2008 to the first half of 2012, the average annual growth of tourists was close to $15 \%$, but the second half of 2012 showed a recession of $-8 \%$ compared with the 
level for the previous year. Two main reasons explain this reversal. Strong competition came from nearby regions where rural tourism has been newly developed and appealed to a certain number of tourists from Baofu town's potential market. More seriously, the declining quality of Baofu town's rural tourism caused by environmental despoliation and service quality deterioration negatively influenced tourists' experience and pushed tourists away. To be one of the earliest towns to develop the rural tourism, the environment pollution of Baofu town emerged earlier than others.

The recession of Baofu town's rural tourism called for local governmental action. From March 2013 to May 2014, tourism experts were invited to diagnose the causes of the recession, improve administration practices, and advise the reconstruction of supply chain. It was the first project of supply chain construction in the surrounding area, which made it an accessible sample. One of the authors was involved in this analysis and thus obtained detailed data for a contextual analysis, allowing this study to be tracked from the very beginning of the supply chain construction project.

\subsection{Methodology: Data Collection and Analysis}

The case study method is ideal when a holistic, in-depth investigation is needed, and the research sample is very small [57]. Since the reconstruction of green TSC in a rural tourism destination is an emerging phenomenon and is scarcely found in the tourism industry in China, the case of Baofu town is useful to understand the evolution of green TSC for rural tourism in China.

Data were taken from primary and secondary sources throughout the overall project. The research was conducted primarily through interviews, observations, brainstorming sessions, archival sources and some public information. The arrangement of the study and rationale of the research design are demonstrated in Table 1. In each of the three stages of the study, the research objectives were set, and multiple methods were adopted to improve the validity of data collection.

Table 1. Research methods and design.

\begin{tabular}{|c|c|c|c|}
\hline Stage & Research Objectives & $\begin{array}{l}\text { Examples of Research } \\
\text { Questions }\end{array}$ & Information Source \\
\hline \multirow{3}{*}{ Before the project } & $\begin{array}{l}\text { Construct theoretical logic and define } \\
\text { the requirement of research sample }\end{array}$ & $\begin{array}{l}\text { Why did town government } \\
\text { launch the project? }\end{array}$ & Public information \\
\hline & Understand the context of the project & $\begin{array}{l}\text { How serious is the } \\
\text { environmental problem in } \\
\text { local tourism? }\end{array}$ & Archival documentation \\
\hline & $\begin{array}{l}\text { Collect basic information of the sample } \\
\text { town and validate the } \\
\text { archival information }\end{array}$ & $\begin{array}{l}\text { How do you describe the local } \\
\text { environment comparing that } \\
\text { before tourism development? }\end{array}$ & Interviews \\
\hline \multirow{3}{*}{ During the project } & $\begin{array}{l}\text { Understand environmental and } \\
\text { efficiency issues in rural tourism } \\
\text { development and details in promoting } \\
\text { TSC from perspective of government, } \\
\text { industry, tourists and residents. }\end{array}$ & $\begin{array}{l}\text { What are the main reasons } \\
\text { causing the environmental and } \\
\text { cost problems? }\end{array}$ & Interviews \\
\hline & $\begin{array}{l}\text { Know the actual situation of the } \\
\text { efficiency and environmental effects }\end{array}$ & & Observations \\
\hline & $\begin{array}{l}\text { Collect documentary data to } \\
\text { understand the cost efficiency of TSC } \\
\text { and also to validate the information } \\
\text { from other sources }\end{array}$ & & Archival documentation \\
\hline After the project & $\begin{array}{l}\text { Understand the green TSC influences } \\
\text { on environment and efficiency from } \\
\text { different perspectives }\end{array}$ & $\begin{array}{l}\text { Does Green TSC boost tourism } \\
\text { development in both efficiency } \\
\text { and environment? }\end{array}$ & Panel Discussion \\
\hline
\end{tabular}

The interviews and observations became the main approaches since they had proven to be effective in collecting detailed information and increasing the reliability of information collected. The profile of the interviewees was presented in Table 2. First, different groups were interviewed on a one-to-one basis. Interviews with the mayor of Baofu town and three key administrators from the Management \& Service Center, which is an administrative organization set up by local government to take 
responsibility of rural tourism administration, were undertaken to understand environmental issues of rural tourism development and details in improving the TSC from local authorities' perspective. Three officers, two of whom are environmental experts, from the environmental department of the Anji County to which the Baofu town belongs expressed their viewpoints and shared information about environmental effects of the TSC. In addition, three local rural tourism business owners and two managers from tier 2 suppliers were interviewed to collect information on strategic and operational issues of TSC construction and were asked to provide their comments on the related government policies and actions. Unstructured interviews were also conducted with 15 tourists and 8 local residents to obtain their viewpoints about rural tourism development and feelings of environment in Baofu town. The governmental administrators were selected on the basis of their position and local business operators, residences and tourists were selected randomly. The interview times varied from $20 \mathrm{~min}$ to $50 \mathrm{~min}$. Information was tape-recorded and transcribed for content analysis.

Table 2. Profile of Interviewees.

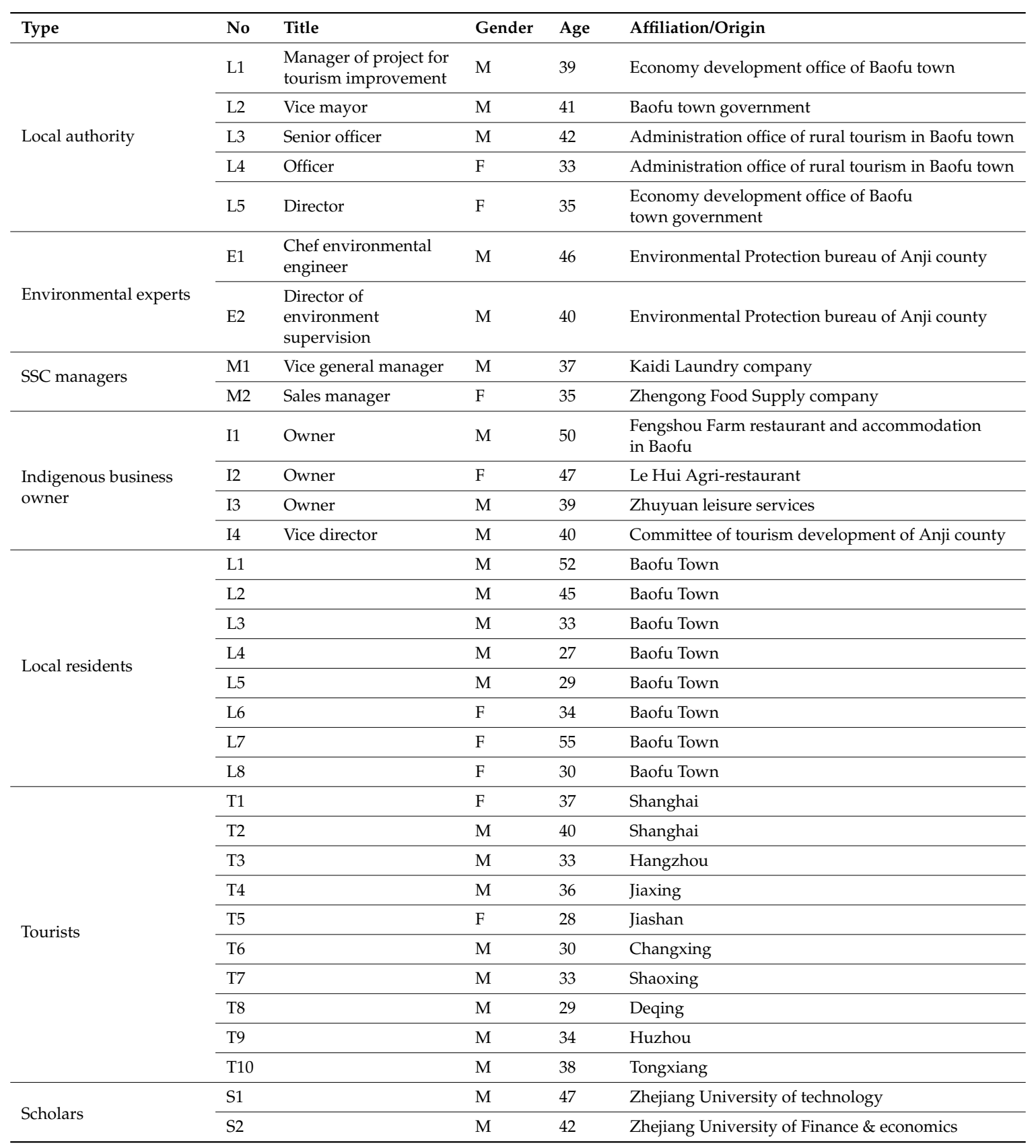


Second, observations were made in some selected family-run hotel businesses before and after the green TSC construction project regarding the operational efficiency and change of environment. Notes were recorded on each observation. Observations also played an important role in validation of data from other sources. Third, two brainstorming sessions were conducted after the project had been completed. The participants in the first session included local government administrators, environmental experts, family-run hotel owners, food material and laundry suppliers, tourist representatives, and local residents. Several participants from local government and suppliers had been interviewed face-to-face while others were newly and randomly selected. During the brainstorming, participants were encouraged to express their feelings on the reconstruction project and give suggestions for further improvement. In the second brainstorming, scholars with expertise in the areas of tourism and environment were invited to analyze the reconstruction project and the theoretical framework proposed by researchers. Detailed notes on brainstorming were recorded.

Fourth, archival documentation including a customer survey was undertaken by local town governments and some family-run hotel owners, and financial statistic tables, complaint records, convention memo, and other related documents from different groups involved in the reconstruction project were collected and used as references to validate data from other sources. Finally, public information was used for a theoretical framework and, most importantly, for validation of data. To some extent, this information could be obtained from relevant newspaper articles in China and the annual working report of Anji county government, to which Baofu town belongs. The articles published in the local newspaper confirmed the problems of profitability and environmental pollution facing Baofu town's rural tourism, while the annual working report of Anji county government supported the recovery of rural tourism in Baofu town after the project.

The collected data were thoroughly reviewed by the authors individually in the first round to identify the underpinning causes, the process of green TSC construction, and administrative issues closely related to the formulation of the green TSC model for rural tourism. In the second round, authors discussed individual findings and generated agreements on group findings. Later, in the third round, several experts from local government and related academic areas were invited to review the group findings. Based on the feedbacks from the panel discussion, the authors modified and improved the primary findings. The next section presents the final results of this analysis.

\subsection{Validity of the Case Study}

Despite many criticisms of the case study method, a case study can be objective if data collection meets the requirements of construct validity, internal validity, external validity, and reliability [58]. To achieve construct validity, a thorough literature review (secondary data) was conducted by which key concepts in the study were defined and clarified and a holistic theoretical framework was constructed. Hence the data collection could be undertaken systematically in light of the theoretic framework already built. To increase internal validity, the data were collected through various sources consisting of interviews, observations, brainstorming sessions and archival sources, as stated above.

External validity reflects whether the findings are generalizable beyond the immediate case. This to some extent could be determined by relevant articles in the newspapers in China and the annual working report of Anji county government. The articles published in the local newspaper confirmed the problems of profitability and environmental pollution that Baofu town's rural tourism faced. The annual working reports of Anji county government supported the recovery of rural tourism in Baofu town after the project.

Reliability was achieved by ascertaining whether evidence from different sources in the research covered a similar set of facts. Accuracy in data collection was apparent when all the evidence had been reviewed. Once the initial case study narrative was recorded, the content of documents was examined by the main information providers. Such a review was not only a necessary procedure for validating the data collection, also a courtesy to those persons who had provided information. 


\section{Findings}

\subsection{Problem Diagnose of Rural Tourism in Baofu Town}

\subsubsection{Environment Pollution and the Vicious Circle It Caused}

The development of rural tourism in Baofu town tragically did not escape from the track of the "tragedy of the commons" [13]. Increasing numbers of visitors attracted more indigenous people, and even outside investors, who came for opening their personal businesses. These businesses scrambled for water from groundwater and nearby lakes and streams, and at the same time discharged untreated sewage into the natural water system and cooking oil fumes into the atmosphere and produced and dumped huge amounts of solid trash. To accommodate more tourists, many business owners or operators occupied farmland or public land to enlarge their farmhouses, often to build back-stage facilities such as kitchens, laundry rooms and storage rooms to meet the expansion of visitors. As the illegal use of land usually did not pass through an environmental evaluation, the new constructions had great potential to contaminate the land. Furthermore, the unplanned expansion of buildings destroyed the landscape of rural area and had negative influence on the environment in terms of attracting tourists to the rural area.

The environmental deterioration caused by the immoderate waste discharge and public resource plunder triggered a vicious circle. The degradation of the environment negatively influenced the image of the destination and also reduced tourists' destination experience. A certain number of tourists were expelled. Around the end of 2011, the supply market exceeded the demand market because of the constant decrease of tourists and increase of family-run hotels. Business owners/operators employed low-price competition to maintain their market share, and the easiest way to maximize the profit was to reduce operational costs by decreasing service quality. According to the statistics from the local government, complaints about services from the visitors had increased steadily since August 2010, with most complaints focused on food quality, sanitation of accommodations, and the attitude of staff. The poor quality of service further pushed tourists away.

\subsubsection{Analysis of Causes}

The analysis of causes includes two parts. The first part examines different sources of environmental pollution. Application of front- and back-stage decoupling theory to the green TSC can be supported by identifying and classifying the sources of pollution in terms of different service functions. The examination of environmental pollution sources related to rural tourism in Baofu town indicated two categories of pollution sources: pollution from the tourists themselves and pollution from tourism facilities and functions, which could be further classified into two sub-categories: pollution from the front-stage functions (facilities) and pollution from the back stages.

As shown in Table 3, the back-stage function/facilities produced all four pollution types-air, water, solid, and noise pollution-while the front stage had three types. As similar research in China held that the pollution produced by back-stage functions/facilities was much more serious than pollution produced by the front stage $[59,60]$, food processing and laundry, two important back-stage functions/facilities in this case, had been accused of contributing the largest portion of pollution to the environment. According to the interviews of local environmental experts, the water quality has decreased in recent years due to the discharge of laundry water and food trash into rivers. The rivers sometimes became very smelly.

The second part of the analysis focuses on the reasons for rural tourism business operators' environment-unfriendly behavior. Private rural tourism businesses have an incentive to "milk the product" without regard to their own responsibilities as stakeholders in the destination [61]. Since installations of environmental protection facilities processing the increasing trash, sewage, and noise are costly for rural tourism business operators, these operators tend to discharge contaminants directly into nature to avoid increasing their operational expenditure. Rural tourism business 
operators argued that environmental protection is "the business of government." Also, they considered themselves to be followers who merely imitated peers' behaviors. If they invested much on the environmental protection, the heavy cost would lead to higher prices of their products, which would decrease the competitiveness of their businesses.

Table 3. The sources and types of pollution for rural tourism in Baofu town.

\begin{tabular}{|c|c|c|c|}
\hline Sources of Pollution & & Pollution Description & Pollution Types \\
\hline \multirow{4}{*}{ Front stage } & Dining facilities & $\begin{array}{l}\text { Trash and waste water from the left-over } \\
\text { and packages }\end{array}$ & SP, WP \\
\hline & Accommodation facilities & $\begin{array}{l}\text { Trash from the one-off toiletries, } \\
\text { stationaries, waste water for day use }\end{array}$ & SP, WP \\
\hline & Leisure facilities & Noise and some trash from food/drinks & NP, SP \\
\hline & Toilets for tourists & Drainage water and residue & WP, SP \\
\hline \multirow{6}{*}{ Back stage } & Food processing & $\begin{array}{l}\text { Waste water and oil, oil fume, smell } \\
\text { and smoke, food/materials and residue } \\
\text { and packages, noise produced in } \\
\text { kitchen operations }\end{array}$ & $\mathrm{WP}, \mathrm{SP}, \mathrm{NP}, \mathrm{AP}$ \\
\hline & Heating and air conditioning & $\begin{array}{l}\text { Waste gas, water dust and noise in heating } \\
\text { or cooling conditioning operations }\end{array}$ & $\mathrm{AP}, \mathrm{WP}, \mathrm{NP}$ \\
\hline & Laundry & Waste water and noise & WP, NP \\
\hline & Storage & Trash in storing goods & SP \\
\hline & Operation offices & Trash from everyday office work & SP \\
\hline & Toilets for employees & Drainage water and residue & $\mathrm{WP}, \mathrm{SP}$ \\
\hline
\end{tabular}

Note: SP: Solid trash pollution; WP: Water pollution; NP: Noise pollution; AP: Air pollution.

\subsection{Process of Green TSC Construction for Baofu Town's Rural Tourism}

\subsubsection{The Implementation of Green TSC's New Structure}

The diagnosis of the problems stated above shed light on the direction of green TSC construction. According to the analysis, the major sources of pollution are generated by back-stage functions, specifically food-processing and laundry. The model presented above shows the possibility of decoupling some back-stage functions from corporations. Shared service centers are established to offer food-processing, laundry, and waste-processing functions for family-run hotels, hotels, and restaurants in the town, as the model suggested. To minimize negative influences on the environment, the locations of these shared service centers are distanced from the rural tourism area.

In the new structure of green TSC, the food processing shared service center serves as an intermediary between local or outside food corporations (tier 3) and local restaurants (tier 1). Food has been purchased from these corporations and delivered to the center by logistics. The food-processing shared service center processes the food, including cleaning, slicing, and mixing ingredients, and delivers the pre-processed food to local restaurants. The logistics between laundry and environmental protection shared service centers and rural tourism businesses differ from the above process. Linens or wastes are collected from tier 1 suppliers and processed in the centers, and then either returned to their owners or transported to recycling or disposal corporations. The products supplied by shared service centers have a unified standard to ensure quality. Also, the concentrated treatment can reduce pollution since processing pollution from individual businesses is minimized and high-tech equipment can be used for pollution treatment.

The implementation of shared service centers in Baofu town demonstrates the possibility of turning theory into destination practice. The practice of green TSC is more complicated than the theoretical model indicates. For example, logistics between different tiers of suppliers might not be unidirectional, as they can be bidirectional or even net-like. Besides the structure of green TSC, the ways that suppliers operated and cooperated also are critical to the success of green TSC for 
rural tourism, which might not be shown in the model. Moreover, only Baofu town implement shared centers dealing with intangible products. Implementation of shared service centers providing intangible products can be helpful to the optimization of the model, since it has different logistical and operational methods.

\subsubsection{Operations of Shared Service Centers}

Both commercial and noncommercial operational methods have been applied to shared service centers. The laundry shared service center was initially operated by several rural tourism business operators/owners who were authorized by the town government, which invested and held a few shares of the laundry service center. Most operational costs were covered equally by the members. More than $90 \%$ of family-run hotels in the town were to be members and outsource their laundry works to the service center. However, because full-time staff was lacking, the efficiency and effectiveness of the laundry shared service center could not meet members' expectations. Subsequently, a professional laundry corporation was invited to invest and enlarge the laundry shared service center, and because the professional management the service capability and qualities were increased, and now small and medium-sized hotels as well as family-run hotels utilize its service. The food-processing shared service center has been operated commercially from the very beginning. Around $60 \%$ of family-run hotels purchase food from the center for better food quality at cheaper prices. Recently, a larger food-processing center has begun construction in Baofu town to provide wider ranges of semi-processed food and materials for family-run hotels and other kinds of restaurants. In sum, shared service centers operated by commercial corporations are more professional and efficient than centers run by government or operators/owners of rural tourism businesses.

The supply relation between the rural tourism business operators/owners and the shared service centers had been consolidated in the form of commercial contract, in which supplying price, distribution time and supplying quality standards had been fixed. To get a fair contract with the shared service center, the small business operators constructed an association supported by the town government. The town government not only supervised whether operations of both shared service center and rural tourism business operators (association) could meet the quality standards and environmental requirements, but also served as an arbitrator or mediator in case of business dispute. Regular meetings among three parties, namely the shared service centers, the association of rural tourism business operators and the town government, were held quarterly to coordinate the business activities, discuss the measures for quality improvement and environment protection, and review the contracts if necessary.

\subsubsection{A Top-Down Approach to Construction}

Normally, two approaches-bottom-up and top-down-can be used to structure the supply chain for a region [62]. Adopting a top-down approach, Baofu town government plays a significant role in promoting the construction of green TSC. First, the administration office of rural tourism established two new departments under the town government to administer shared service centers (Figure 2). The back-stage supporting department supervises shared service centers and coordinates the relationships between rural tourism business operators/owners and managers of shared service centers. The environmental protection department inspects the local environment and monitors the environmental protection shared service center. Second, other departments of the office of rural tourism are also involved in the supply chain construction. The standardization department evaluates the establishment application of shared service centers in terms of location selection and waste and pollution treatment. The liaison department is responsible for negotiating with related organizations and institutions, such as environmental protection agencies, land management offices, and hotel and restaurant associations, to facilitate the construction of shared service centers. Third, the town government agrees on a favorable taxation policy to encourage corporations to invest in shared service centers. Furthermore, the town government gives a certain subsidy to encourage local 
business operators/owners to use shared service centers. This top-down approach has accelerated the construction of green TSC in Baofu town and attracts investors. Around US\$10 million was invested into laundry, food processing, and other tourism-related business in the first half of 2013 for the entire town. Also, more rural tourism businesses now purchase products from the shared service centers. More back-stage functions, such as marketing, employ training programs, were decoupled in 2015. A state-owned corporation was established to operate shared service centers for new back-stage functions.

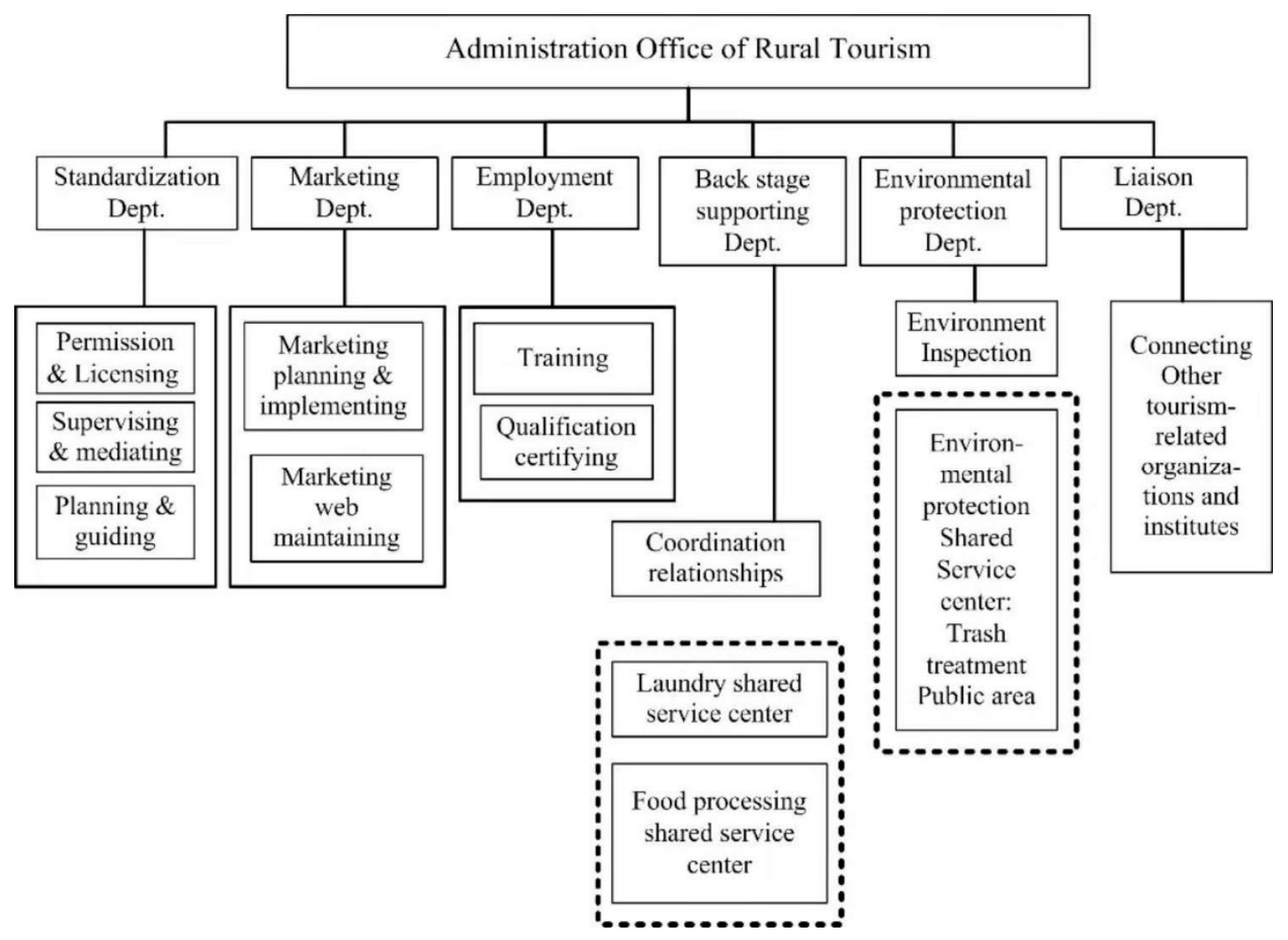

Figure 2. The departmental structure of the management service center in Baofu town. Note: Functions presented in squares with dotted line are operated by shared service centers.

\subsection{The Effects of New Green TSC Structure in Baofu Town}

The effects of green TSC were assessed ten months after the construction through examination of government reports and investigation of effects on rural tourism business owners/operators. The support from shared service centers assists a large number of rural tourism business owners/operators in streamlining their service system by reducing some of the back-stage functions. Records show that $90 \%$ of them had cut off their laundry and over $60 \%$ now purchase semi-processed food materials from the catering centers and have reduced the size of their kitchen areas. Environmental pollution has been alleviated substantially. The environmental department of the Anji county government has examined the pollution status of Baofu town and found that it has been greatly improved. Some pollution sources, especially those from laundry activities and food processing, have been eliminated, as these activities are centrally processed in the shared service centers. Other types of waste also have been carefully disposed of by environmental shared service centers. A report of environmental impact assessment in 2015 showed that the development of rural tourism in Shiling village, Baofu town had limited influence on environment [63]. According to the investigation from professional detection company, the quality of air and water were satisfied. The air pollutants, such as $\mathrm{SO}_{2}, \mathrm{NO}_{2}$, and $\mathrm{PM}_{10}$, in most days of the year, reached the standard of National Ambient Air Quality 
Standard (GB3095-2012). The quality of water also met the II level of National Standard of Surface Water (GB3838-2002). In 2017, Anji country received the China habitat environment prize.

Because of environmental improvement, tourists are now attracted to visit and enjoy a cleaner and more beautiful landscape in Baofu town. Tourist arrivals have increased since July 2012 and brought profits to local business, which satisfied those rural tourism business operators. On the other hand, because of the scale effect of the shared service centers' operation, rural tourism business owners/operators save on laundry and food-processing costs. The laundry cost of a sheet, for example, would be US\$0.13-0.14 when the laundry is done by individual businesses. The cost can be reduced to US $\$ 0.1-0.11$ by utilizing the laundry service center. The decline of costs relieved rural tourism business owners' / operators' concerns as to which practices of environmental protections would increase their operational costs.

\section{Discussion and Conclusions}

\subsection{Academic Implications}

The growth of rural tourism brings benefits to the rural area but causes environmental issues in China. A rough method to solve the environmental pollution is to close down those small businesses without considering local peoples' well-being. A better solution would be to achieve a balance between tourism development (economic efficiency) and environmental pollution, which is a basic principle of sustainable rural tourism [64]. This paper, through a case study of rural tourism in China, proposes a new structure of green TSC for rural tourism destination to obtain sustainable development. Through this analysis a new tier of upstream suppliers, consisting of shared service centers with back-stage functions, is added, producing a new structure. This modification considers the natural feature of service industry, follows the principle of scale effect, and integrates the theory of front- and back-stage decoupling and green TSC for a destination. Rather than following a manufacture-based research path, as most green TSC literature has done (e.g., [37,65,66]), this study grasp the fundamental feature of rural tourism as a service provision characterized with front-back stage structure. Based this understanding, the paper integrates the concept of front-back stage decoupling which is the upgraded new service system structure and can improve both efficiency and environmental situation, into the restructuring of green TSC of rural tourism, leading to the solution of similar contradiction between sustainability (environment) and local development (efficiency). This hence offers a new perspective and path to deepen the research of green TSC by taking into account the key feature of services and integrating concept of new service system structure. The study also enriches the research of sustainable and rural tourism from an operational view, in particular system structure design.

\subsection{Practical Implications}

The rural tourism of Baofu town consists of many small-scale businesses, each of which had been a self-sufficient system characterized with "complete" front-back stage functions. However, when all businesses in the region were viewed as a whole, many back-stage functions/facilities of individual units were redundant, leading to inefficient resource use. In addition, since these back-stage functions had been operated on a small scale in each business, operators and owners had limited willingness to invest technology innovation. Thus, the small-scale and low-tech features of many businesses' back-stage facilities do not decrease environment pollution and increase resource utilization. New forms of cooperation must be encouraged between rural tourism businesses $[67,68]$. Decoupling the back-stage functions from small businesses and assembling them into larger scale operations has several advantages. The scale effect makes the treatments of pollution more efficient and also saves land, water, and energy resources. To eliminate negative influences on the environment, shared service centers can be located in remote areas away from touristic and residential districts. Also, the pressure of environmental facility investment for small business is reduced, which could bring them more disposable money for business development. 
In constructing the green TSC, the top-down approach proved to be useful. One of the government's responsibilities is to ensure a better business environment for local corporations [60]. Without the efforts and coordination of local governments, the construction of TSC would not be happen so quickly and smoothly. Normally there could be another bottom-up approach. That means businesses owners/operators show great interests on shared service centers and ask government to help them on the construction. However, this phenomenon had not been appeared in Baofu town. The small businesses owners might lack of the knowledge on supply chain construction. Also, they did not realize the importance of environment protection and want to make change. Therefore, local government plays a very important role in facilitating the establishment of shared service centers by organizing small businesses to participate and by providing initial resources. However, the government per se is not able to supply products to the small businesses. The commercialization of back-stage functions is also critical. In this case, the local government invited corporations to invest in the laundry and food-processing centers. Specialized corporations show greater productivity through specialization, standardization, and consideration of business processes [69]. Meanwhile, the involvement of specialized corporations as tier 2 suppliers depends strongly on the local government for support. Favorable taxation or land use policies offered by local governments facilitate the establishment of shared service centers, as policy consideration has been approved as an efficient tool for the government to intervene in local business [60]. In sum, the top-down approach is very important at the beginning of the construction of the supply chain. During the construction, the involvement and cooperation among government, specialized corporations and small businesses are critical for success.

\subsection{Limitations and Future Research}

The conceptual framework of green TSC for rural tourism needs more evidence supporting the relationships among upstream suppliers and between upstream suppliers and downstream customers. To make the results of this study more generalizable, deep and detailed analysis is needed. For example, how many rural tourism businesses in the region that is willing to decouple their back-stage functions and attend the shared service centers can reach the scale effects? A closely related question would be how to decide the operational scale of shared service center. By answering these questions, research can offer more recommendations to regional authorities and rural tourism businesses in terms of adopting the new structure of TSC.

In addition, managerial issues of green TSC can be explored. For example, further research is required to discern how to coordinate the different tiers of suppliers and deal with the relationships between shared service centers and individual business, since the added tier of suppliers complicates the structure of green TSC. Also, what other back-stage functions can be decoupled from the individual business besides those mentioned in the paper? Both the academic research and managerial implications could be explored more in the future.

Author Contributions: Conceptualization and writing-original draft preparation Jingjing Guan; Methodology, investigation, and data analysis Jue Chen; writing_-review and editing, Jing (Bill) Xu and Cecile Clergeau.

Funding: This research was funded by the National Natural Science Foundation of China, grant number: 41701166; China Scholarship Council, grant number: 1201708330456; National Social Science Foundation of China, grant number: 18BGL145; Social Science Foundation of Zhejiang Province, grant number: 18NDJC182YB; Social Science Foundation of Hangzhou, grant number: Z18JC047; Special Fund from Central Finance to Support Local University $(1,16)$.

Acknowledgments: The authors would like to thank Muzzo Uysal for his valuable insights and comments on the manuscript; Guobin Ma for his assistance on Figure drawing; three anonymous reviewers' review.

Conflicts of Interest: The authors declare no conflict of interest. 


\section{References}

1. Sharpley, R. Rural tourism and the challenge of tourism diversification: The case of Cyprus. Tour. Manag. 2002, 23, 233-244. [CrossRef]

2. Sharpley, R. Flagship attractions and sustainable rural tourism development: The case of the Alnwick Garden, England. J. Sustain. Tour. 2007, 15, 125-143. [CrossRef]

3. Truong, V.D.; Hall, C.M.; Garry, T. Tourism and poverty alleviation: Perceptions and experiences of poor people in Sapa, Vietnam. J. Sustain. Tour. 2014, 22, 1071-1089. [CrossRef]

4. Sharpley, R.; Roberts, L. Rural tourism-10 years on. Int. J. Tour. Res. 2004, 6, 119-124. [CrossRef]

5. Keyim, P. Tourism and rural development in western China: A case from Turpan. Community Dev. J. 2016, 51, 534-551. [CrossRef]

6. Quaranta, G.; Citro, E.; Salvia, R. Economic and social sustainable synergies to promote innovations in rural tourism and local development. Sustainability 2016, 8, 668. [CrossRef]

7. Deng, Y.M. Rural eco-environmental problems and countermeasures in China. Agric. Econ. 2017, 4, 38-40. (In Chinese)

8. Bramwell, B. Rural tourism and sustainable rural tourism. J. Sustain. Tour. 1994, 2, 1-6. [CrossRef]

9. Villanueva-Álvaro, J.J.; Mondéjar-Jiménez, J.; Sáez-Martínez, F.J. Rural tourism: Development, management and sustainability in rural establishments. Sustainability 2017, 9, 818. [CrossRef]

10. China Ministry of Agriculture. Research Report on China's Leisure Agriculture and Rural Tourism Development; China Ministry of Agriculture: Hangzhou, China, 2017. (In Chinese).

11. Liao, Y.; Nong, D. Analysis of the impact of rural tourism on Farmers' income and environment-Taking Fuxian Lake in Jiangchuan County of Yunnan Province as an example. Glob. Hum. Geogr. 2016, 6, 168-169. (In Chinese)

12. Wu, D.; Hu, W. A study on the impact of rural tourism development on Tourist Destinations-A case study of Guan Hou Village, Xianju County, Zhejiang Province. Rural Econ. Sci. Technol. 2017, 28, 77-79. (In Chinese)

13. Chi, J.; Cui, F.J. A Study on "The Tragedy of the Commons" in the Process of the Development of On-limits Rural Tourism Destinations-A Case of Meijiawu, Longwu and Shangougou in Hangzhou. Tour. Trib. 2006, 21, 17-23. (In Chinese)

14. Choo, H.; Jamal, T. Tourism on organic farms in South Korea: A new form of ecotourism? J. Sustain. Tour. 2009, 17, 431-454. [CrossRef]

15. Carlsen, J.; Getz, D.; Ali-Knight, J. The environmental attitudes and practices of family businesses in the rural tourism and hospitality sectors. J. Sustain. Tour. 2001, 9, 281-297. [CrossRef]

16. Chen, Z.; Meiwei, W.; Rongde, L. Goodbye, Dali: Hip Tourist Spot Turns Into Ghost Town as Sewage Scare Prompts Shutdown. Available online: https://www.caixinglobal.com/2017-05-18/goodbye-dalihip-tourist-spot-turns-into-ghost-town-as-sewage-scare-prompts-shutdown-101092172.html (accessed on 3 April 2018).

17. Bitner, M.J.; Ostrom, A.L.; Morgan, F.N. Service blueprinting: A practical technique for service innovation. Calif. Manag. Rev. 2008, 3, 66-97. [CrossRef]

18. Boon-itt, S.; Wong, C.Y.; Wong, C.W. Service supply chain management process capabilities: Measurement development. Int. J. Prod. Econ. 2017, 1, 1-11. [CrossRef]

19. Sampson, S.E.; Spring, M. Service supply chains: Introducing the special topic forum. J. Supply Chain Manag. 2012, 4, 3-7. [CrossRef]

20. Maull, R.S.; Geraldi, J.; Johnston, R. Service supply chains: A customer perspective. J. Supply Chain Manag. 2012, 4, 72-86. [CrossRef]

21. Randall, W.S.; Pohlen, T.L.; Hanna, J.B. Evolving a theory of performance-based logistics using insights from service dominant logic. J. Bus. Logist. 2010, 2, 35-61. [CrossRef]

22. Selviaridis, K.; Matopoulos, A.; Szamosi, L.T.; Psychogios, A. Reverse resource exchanges in service supply chains: The case of returnable transport packaging. Supply Chain Manag. 2016, 21, 381-397. [CrossRef]

23. Xu, H.; Zhou, X. The construction of conceptual model of tourist destination supply chain. Tour. Sci. 2009, 23, 15-20. (In Chinese)

24. Tapper, R.; Font, X. Tourism supply chains: Report of a desk research project for the travel foundation. Available online: http:/ / www.icrtourism.com.au/wp-content/uploads/2012/09/TourismSupplyChains. pdf (accessed on 5 March 2018). 
25. Zhang, X.; Song, H.; Huang, G.Q. Tourism supply chain management: A new research agenda. Tour. Manag. 2009, 30, 345-358. [CrossRef]

26. Sarkis, J.; Zhu, Q.; Lai, K.H. An organizational theoretic review of green supply chain management literature. Int. J. Prod. Econ. 2011, 130, 1-15. [CrossRef]

27. Carter, C.R.; Rogers, D.S. A framework of sustainable supply chain management: Moving toward new theory. Int. J. Phys. Distrib. Logist. 2008, 38, 360-387. [CrossRef]

28. Srivastava, S.K. Green supply chain management: A state-of-the art literature view. Int. J. Manag. Rev. 2007, 9, 53-80. [CrossRef]

29. Zhu, Q.; Sarkis, J. An inter-sectoral comparison of green supply chain management in China: Drivers and practices. J. Clean. Prod. 2006, 14, 472-486. [CrossRef]

30. Testa, F.; Iraldo, F. Shadows and lights of GSCM (green supply chain management): Determinants and effects of these practices based on a multinational study. J. Clean. Prod. 2010, 18, 953-962. [CrossRef]

31. Laari, S.; Töyli, J.; Solakivi, T.; Ojala, L. Firm performance and customer-driven green supply chain management. J. Clean. Prod. 2016, 112, 1960-1970. [CrossRef]

32. Tseng, M.L.; Bui, T.D. Identifying eco-innovation in industrial symbiosis under linguistic preferences: A novel hierarchical approach. J. Clean. Prod. 2017, 140, 1376-1389. [CrossRef]

33. Islama, M.S.; Tseng, M.L.; Kariaa, N.; Leed, C.H. Assessing green supply chain practices in Bangladesh using fuzzy importance and performance approach. Resour. Conserv. Recycl. 2018, 131, 134-145. [CrossRef]

34. Sigala, M. A supply chain management approach for investigating the role of tour operators on sustainable tourism: The case of TUI. J. Clean. Prod. 2008, 16, 1589-1599. [CrossRef]

35. $\mathrm{Xu}, \mathrm{H}$. Research on the impact of supply and demand environment change on the connotation of tourism destination supply chain. J. Beijing Int. Stud. Univ. 2009, 173, 14-19. (In Chinese)

36. Xu, X.; Gursoy, D. A conceptual framework of sustainable hospitality supply chain management. J. Hosp. Mark. Manag. 2015, 24, 229-259. [CrossRef]

37. Fadeeva, Z. Translation of sustainability ideas in tourism networks: Some roles of cross-sectoral networks in change towards sustainable development. J. Clean. Prod. 2005, 13, 175-189. [CrossRef]

38. Edgell Sr, D.L. Managing Sustainable Tourism: A Legacy for the Future, 2nd ed.; Routledge: New York, NY, USA, 2016; ISBN 9781138918634.

39. Wu, D. Supply chain construction in low carbon tourism. Spec. Zone Econ. 2011, 11, 178-180. (In Chinese)

40. Wang, F. The Operation Research about Green Tourism Supply Chain with Scenic Spots as Core-enterprises. Zhejiang Ocean. Univ. Hum. Sci. 2010, 27, 52-55. (In Chinese)

41. Zhang, H. Applying the green supply chain management on the development of ecotourism products. Product. Res. 2007, 2, 132-134. (In Chinese)

42. Zhou, X.; Wang, Y.Q. The study on the rural tourism green supply chain in the urban economy influencing zone. Res. Admin. Sci. 2013, 6, 1-4. (In Chinese)

43. Thompson, J.D. Organizations in Action: Social Science Bases of Administrative Theory, 7th ed.; Transaction Publishers: Piscataway, NJ, USA, 2010; ISBN 0765809915.

44. Chase, R.B. The customer contact approach to services: Theoretical bases and practical extensions. Oper. Res. 1981, 29, 698-706. [CrossRef]

45. Metters, R.; Vargas, V. A typology of decoupling strategies in mixed services. J. Oper. Manag. 2002, 18, 663-682. [CrossRef]

46. Safizadeh, M.H.; Field, J.M.; Ritzman, L.P. An empirical analysis of financial services processes with a front-office or back-office orientation. J. Oper. Manag. 2003, 21, 557-576. [CrossRef]

47. Chen, J.; Hao, Y. Front-back stage decoupling of service system from traditional operation to mass customization. China Ind. Econ. 2009, 10, 108-117. (In Chinese)

48. Schulz, V.; Brenner, W. Characteristics of shared service centers. Transform. Gov. People Process Policy 2010, 4, 210-219. [CrossRef]

49. Apte, U.M.; Mason, R.O. Global disaggregation of information-intensive services. Manag. Sci. 1995, 41, 1250-1262. [CrossRef]

50. Breathnach, P. Globalisation, information technology and the emergence of niche transnational cities: The growth of the call centre sector in Dublin. Geoforum 2000, 31, 477-485. [CrossRef]

51. Lacity, M.; Willcocks, L.; Teeny, D. Commercializing the back office at Lloyds of London: Outsourcing and strategic partnerships revisited. Eur. Manag. J. 2004, 22, 127-140. [CrossRef] 
52. Zomerdijk, L.G.; de Vries, J. Structuring front office and back office work in service delivery systems: An empirical study of three design decisions. Int. J. Oper. Prod. Manag. 2007, 27, 108-131. [CrossRef]

53. Wang, D. The Development of Tourist Dissipative Structure System: Theory and Practice; China Market Press: Beijing, China, 2006; ISBN 9787509200438. (In Chinese)

54. Chen, J.; Tang, D.; Wang, J. A Comprehensive Cost Analysis on New System Structure for Nature-Based Tourism Destination: Perspective of Front and Back Stage Decoupling. Asia Pac. J. Tour. Res. 2014, 19, 1345-1358. [CrossRef]

55. Bergeron, B. Essentials of Shared Service Centers; John Wiley \& Sons: New York, NY, USA, 2003; ISBN 9780471250791.

56. Utting, P. Social and political dimensions of environmental protection in Central America. Dev. Chang. 1994, 25, 231-259. [CrossRef]

57. Creswell, J. Qualitative Inquiry E Research Design: Choosing among Five Approaches; Sage: Riverside County, CA, USA, 2002; ISBN 978-1412995306.

58. Yin, R.K. Discovering the future of the case study. Method in evaluation research. Eval. Pract. 1994, 15, 283-290. [CrossRef]

59. Deng, Y.M. Counter Measures to environmental and ecological problems in rural tourism in China. Agric. Econ. 2017, 4, 38-40. (In Chinese)

60. Sun, H.L.; Guo, J.; Li, X.F. Rural tourism and environmental pollution problems. Rural Econ. Sci. Technol. 2011, 11, 72-73.

61. Wanhill, S. Sustaining Tourism SMEs. Available online: http:/ / citeseerx.ist.psu.edu/viewdoc/download? doi=10.1.1.138.480\&rep=rep1\&type=pdf (accessed on 8 April 2018).

62. Tseng, M.L.; Tan, R.R.; Siriban-Manalang, A.B. Sustainable consumption and production for Asia: Sustainability through green design and practice. J. Clean. Prod. 2013, 40, 1-5. [CrossRef]

63. Hangzhou Tianchuan Environmental Technology Co. Environment impact assessment of rural tourism in Shiling village, BaofuTown. Available online: http:/ / www.doc88.com/p-9089790309806.html (accessed on 25 October 2018).

64. Neto, F. A new approach to sustainable tourism development: Moving beyond environmental protection. Nat. Resour. Forum 2003, 27, 212-222. [CrossRef]

65. Amemba, C.S.; Nyaboke, P.G.; Osoro, A.; Mburu, N. Elements of green supply chain management. Eur. J. Bus. Manag. 2013, 5, 51-61.

66. Font, X.; Tapper, R.; Schwartz, K.; Kornilaki, M. Sustainable supply chain management in tourism. Bus. Strategy Environ. 2008, 17, 260-271. [CrossRef]

67. Guzmán, J.; Moreno, P.; Tejada, P. The tourism SMEs in the global value chains: The case of Andalusia. Serv. Bus. 2008, 2, 187-202. [CrossRef]

68. Hwang, L.J.; Lockwood, A. Understanding the challenges of implementing best practices in hospitality and tourism SMEs. Benchmarking Int. J. 2006, 13, 337-354. [CrossRef]

69. Sako, M. Outsourcing and offshoring: Implications for productivity of business services. Oxf. Rev. Econ. Policy 2006, 22, 499-512. [CrossRef]

(C) 2018 by the authors. Licensee MDPI, Basel, Switzerland. This article is an open access article distributed under the terms and conditions of the Creative Commons Attribution (CC BY) license (http://creativecommons.org/licenses/by/4.0/). 